\title{
WPŁYW SYSTEMU WYCHOWAWCZEGO ŚW. JANA BOSKO NA DZIAŁALNOŚĆ OPIEKUŃCZO-WYCHOWAWCZĄ ZGROMADZEŃ ZAKONNYCH W POLSCE
}

\begin{abstract}
Abstrakt: Święty ksiądz Jan Bosko (1815-1888) był wybitnym wychowawcą młodzieży, twórcą oryginalnego systemu wychowawczego zwanego prewencyjnym (zapobiegawczym). Założył nowe zgromadzenia zakonne - salezjanów - zajmujących się opieką i wychowaniem byłych małoletnich więźniów, opuszczonych i osieroconych chłopców z okolic Turynu. W roku 1872 opiekę nad ubogimi i osieroconymi dziewczętami powierzył nowemu zgromadzeniu Córek Maryi Wspomożycielki (salezjanki). Program opieki nad podopiecznymi był oparty na zasadach wychowania chrześcijańskiego, życiu eucharystycznym wychowanków, których w zakładach i oratoriach otaczano rozumną miłością, przyjaźnią i dobrocią. Podopieczni uczęszczali do zorganizowanych dla nich szkół zawodowych i warsztatów, które w przyszłości dawały im szansę na lepsze życie. Końcem XIX wieku zakon ten został sprowadzony na ziemie polskie, gdzie prężnie się rozwijał.

Z salezjańskich wzorców wychowawczych współcześnie czerpią także inne zgromadzenia zakonne zajmujące się wychowaniem dzieci i młodzieży na ziemiach polskich, tj.: Zgromadzenie św. Michała Archanioła, Zgromadzenie Sióstr św. Michała Archanioła (michalitki), Zgromadzenie Sióstr Pasterek od Opatrzności Bożej, a także stowarzyszenia świeckie działające w tzw. Rodzinie Salezjańskiej.
\end{abstract}

Słowa kluczowe: salezjanie, system prewencyjny, zakony, opieka, wychowanie chrześcijańskie, sieroctwo i opuszczenie 
Ksiądz Jan Bosko (1815-1888) wpisał się na trwałe w historię wychowania i myśli pedagogicznej. Za fundamenty pracy wychowawczej uważał rozum, religię i miłość (Bosco 2002, s. 149; Duchowość salezjańska..., 2007, s. 103-104; Szmidt 2006, s. 26-35). Stworzoną przez ks. Bosko koncepcję pedagogiczną przeciwstawia się zarówno systemowi wychowania represyjnego, jak i nadmiernie pobłażliwego. Nazywana jest systemem prewencyjnym (zapobiegawczym). Głównym celem wychowania jest wielostronny rozwój młodzieży, tak aby wychować ich na uczciwych obywateli i dobrych chrześcijan. Cel ten ma być realizowany przez stworzenie środowiska wychowawczego, które będzie się charakteryzować „rodzinną atmosferą", przygotowanie wychowanków do przyszłego życia, zapobieganie deformującym doświadczeniom, kształtowanie poczucia odpowiedzialności i właściwie pojętej wolności. Ksiądz Bosko jest wzorem pedagoga, który wychowywał młodzież we własnym, niepowtarzalnym stylu, opartym na dialogu, szacunku dla wychowanka i wartościach chrześcijańskich (Łobocki 2004, s. 87; Łuczyński 2012, s. 241-242). Ciągłość jego charyzmatu trwa w Kościele i zgromadzeniu zajmującym się kształceniem i wychowaniem dzieci i młodzieży.

\section{DZIEJE NOWEGO ZGROMADZENIA}

Późniejszy święty ks. J. Bosko (Bosco) był założycielem Towarzystwa św. Franciszka Salezego (Societas Sancti Francisci Silesii). Charyzmatem zgromadzenia jest ewangelizacja i wychowanie młodzieży biednej, opuszczonej i zagrożonej przestępstwem, a często także osieroconej. Zgromadzenie zostało zatwierdzone przez Stolicę Apostolską 19.02.1869 r., a jego Reguły w 1874 r. Beatyfikacja ks. Bosko odbyła się 2.06.1929 r., a kanonizacja 1.06.1934 r., w czasie której papież Pius XI nazwał go „księciem wychowawców” („Wiadomości Salezjańskie” 1897, nr 1, s. 9-13; Wilk 1997, s. 760-762; Łoziński 2008, s. 123-124). Założyciel zgromadzenia urodził się 16.08.1815 r. w pobliżu miejscowości Castelnuovo d'Asti koło Turynu, jego rodzice byli chłopami. Po śmierci ojca wychowywał się w trudnych warunkach. Jako dziecko miał proroczy sen, w którym ujrzał swój przyszły zakres pracy - opiekę nad opuszczoną i wykolejoną młodzieżą. Jako kilkunastolatek musiał opuścić dom rodzinny, pracował w gospodarstwie rodziny Mogli. Od 1828 r. zamieszkał w Buttigliera u księdza Canosso, gdzie podjął regularną naukę. Pracując i ucząc się jednocześnie różnych zawodów, kontynuował naukę od 1831 r. w gimnazjum w Chieri. Równoczesnie dojrzewało w nim pragnienie, aby zostać kapłanem, w 1835 r. wstąpił do Seminarium Duchownego w Chieri. Kolejnym etapem w jego życiu był tzw. okres konwiktorski, w latach 1841-1844 zamieszkiwał w Konwikcie w Turynie, gdzie studiował teologię pastoralną, aby poznać problemy diecezji i lepiej przygotować się 
do późniejszej pracy duszpasterskiej. Rektor Konwiktu ks. G. Cafasso, przełożony, przyjaciel i kierownik duchowy ks. Bosko zwrócił uwagę młodemu księdzu na problemy młodzieży przebywającej w turyńskich więzieniach. Ksiądz Bosko rozpoczął z nimi pracę: regularne odwiedziny, nauka religii, konferencje, kazania z racji świąt i okresów liturgicznych, dostarczanie książek. Kontakty ze skazanymi młodocianymi zwróciły uwagę księdza na młodych ubogich migrantów z różnych miejscowości, którzy przybyli do Turynu, aby znaleźć pracę i środki do życia (Misiaszek 2012, s. 230-231). Wielu z nich było bezdomnych, wykorzystywanych bezwzględnie przez pracodawców, często tworzyli przestępcze grupy, a następnie trafiali do więzień. Opiekując się młodzieżą, jednocześnie przygotowywał się do świeceń kapłańskich, które otrzymał 5.06.1841 r. z rąk arcybiskupa Turynu Alojzego Fransoni (Świda 1984, s. 5-8, 22-23; Niewęgłowski 2003, s. 422-425; Wirth 2009, s. 31-40).

Idea wychowania młodzieży w celu kształtowania przyszłości społeczeństwa była jednym z głównych motywów jego wysiłków, a jej realizacja wypełniała jego życie. Uważał, że działalność wychowawcza winna zmierzać do formowania osobowości ludzkich, wychowania dobrych chrześcijan i obywateli, mających poczucie wspólnoty, solidarności i obowiązków społecznych. Jan Bosko zajął się początkowo młodzieżą bezdomną, biedną i zaniedbaną moralnie. Zakładał kolejno: oratoria, schroniska dla chłopców bezdomnych, warsztaty i szkoły dla młodzieży rzemieślniczej i pracującej, szkoły niedzielne, dzienne, wieczorowe, gimnazja i inne placówki, jak kolegia, ośrodki misyjne i hospicja. W pracy wychowawczej ks. Bosko starał się likwidować wśród młodzieży poczucie kontrastu między nauką a pracą ręczną, by usunąć rosnącą niechęć między uczącymi się a pracującymi fizycznie. Przyzwyczajał swych wychowanków do wspólnego życia, pracy i odczuwania radości niezależnie od spełnianych zajęć, nauki czy pochodzenia, dlatego organizowane przez niego ośrodki wychowawcze nazywano "prawdziwą szkołą demokracji” (Styrna 1974, s. 11; Pietrzykowski 2012, s. 920-922).

Do stworzonego przez siebie ośrodka w Turynie przyjmował młodocianych więźniów, bezdomnych chłopców, których bieda, a często sieroctwo skierowało do szukania pracy w przemysłowych dzielnicach Turynu. Chłopcy mieli możliwość ukończenia szkół o profilu zawodowym. Ks. Bosko wypracował także własny oryginalny styl wychowania. Charakterystycznym miejscem i zarazem formą pracy ks. Bosko było oratorium, które było przestrzenią modlitwy, a modlitwa „kolumną nośną", na której wspierała się cała jego działalność, zaś szczególną rolę odgrywały nabożeństwa ku czci Matki Bożej (Duchowość salezjańska... 2007, s. 51-52). Oratorium korzeniami sięga do czasów renesansu i osoby św. Filipa Neri (1515-1595), który podejmował próby ożywienia i odnowy życia religijnego w Rzymie. Założył on Kongregację Oratorium w 1564 r. Za pośrednictwem tej wspólnoty, którą stworzył, dzięki nowoczesnym metodom, tj.: śpiewanie pieśni religijnych w języku 
narodowym, kazania dla dzieci, pielgrzymki, spotkania modlitewne i dyskusyjne, pragnął odrodzić moralnie ludzkość. Z wprowadzonych przez niego do owych spotkań tzw. pieśni duchowych (laudi spirituali) rozwinął się w XVII w. dramat muzyczny, zwany oratorium (Gorys 2007, s. 120-121). Ksiądz Bosko korzystał z tego dzieła, a jednocześnie adoptował do własnych potrzeb wychowania młodzieży. Celem oratorium było odciągnięcie młodzieży od bezczynności i złego towarzystwa, zwłaszcza w dni świąteczne (Bosko 2002, s. 192-194). Tworzył dom z właściwą mu atmosferą życia rodzinnego, który charakteryzował działalność wychowawczą salezjanów, głównie przez okazywanie wychowankowi szacunku, zaufania, dobroci, miłości. Podstawą wychowania było nawiązanie przez wychowawcę serdecznych relacji z wychowankiem. Myśl o ukształtowaniu takiego właśnie rodzinnego sposobu wychowywania wypływała $z$ własnych doświadczeń ks. J. Bosko, a także z poznania sytuacji wychowanków, którzy w większości nie mieli własnych domów rodzinnych. Metoda wychowawcza stosowana przez salezjanów jest zwana powszechnie systemem uprzedzającym, czyli prewencyjnym św. Jana Bosko; będąc bardziej praktykiem niż teoretykiem wychowania, nie wypracował teoretycznych jego podstaw, dając jedynie ogólne wskazania (Cian 2001, s. 162-164, 269-285; Misiaszek 2012, s. 234-248). W przypadku ks. J. Bosko idea prewencji przyjęła pozytywne ukierunkowanie, będąc wyrazem poszukiwania takich założeń, metod i środków, które pomogłyby uformować pełnego człowieka, wspomagając jego integralnie rozumiany rozwój ludzki i chrześcijański. W polskiej tradycji wychowania prewencyjnego stosowano określenia dobrze oddające ducha tej metody wychowawczej - nazywano go systemem uprzedzającym, zapobiegawczym. Wychowawca był zobowiązany do przyjmowania postawy przewidywania różnych wydarzeń, sytuacji i informowania wychowanka o mogących z nich wynikać określonych konsekwencjach. Jest to znana w wychowaniu zasada, że lepiej jest zapobiegać złu niż się z niego leczyć, poszerzone o element wskazujący na powinność poszukiwania dobra, by na nim budować proces wychowania. Salezjańska metoda wychowawcza prewencyjna jest oparta na trzech podstawowych zasadach wzajemnie się uzupełniających: rozumie, religii i miłości. Działanie wychowawcze ma być przede wszystkim rozumne, racjonalne, a zarazem otwarte na dopełniające rozum doświadczenie religijne, które w przypadku chrześcijaństwa jest wyrażone najpełniej w postawie miłości. Miłość jest wartością przenikającą i spajającą całe dzieło wychowawcze św. Jana Bosko. W systemie uprzedzającym dbano o to, aby wychowanek pod czujnym okiem zawsze obecnego wychowawcy nie miał okazji popełniać wykroczeń. Wszyscy nauczyciele, majstrowie uczący różnych rzemiosł i asystenci mieli być osobami o nienagannej moralności. Zasada religii (religijności) jest traktowana w salezjańskiej metodzie wychowawczej jako podstawowy warunek skuteczności wychowawczej rzutujący na treść, formy, środki wychowania. Częsta 
spowiedź i komunia św., codzienna Msza św. były podstawowymi filarami, na których opierało się całe wychowanie. Nigdy nie zmuszano młodych do przystępowania do sakramentów, jedynie zachęcano i dawano dogodną sposobność korzystania z nich. Taka metoda pracy pedagogicznej miała prowadzić do świętości osobistej zarówno wychowanków, jak i wychowawców; oddanie się dobru podopiecznych, uczestniczenie $\mathrm{w}$ ich życiu z pozycji ojca, brata, przyjaciela oraz traktowanie ich ze szczerą życzliwością, przyjaźnią, a nawet zażyłością stwarzało klimat zaufania w procesie wychowawczym. Ksiądz Bosko zakazywał karcenia fizycznego, poniżania wychowanków, za różne przewinienia stosowano system mądrze dobranych upomnień i nagan, motywowano chłopców do dobrego zachowania przez pochwały i dobre przykłady („Wiadomości Salezjańskie” 1899, R. III, nr 10, 11, s. 291-297; Wilk 1997, s. 760; Misiaszek 2010, s. 455-458).

Pierwsi chłopcy, których ks. Bosko przygarnął z ulicy, gdy już dorośli, zdecydowali się zostać z nim, aby poświęcić się opuszczonym chłopcom. Nowe zgromadzenie powstało 26.01.1854 r. Na początku było tylko czterech zakonników (Bosco 1990, s. 217), ale z czasem liczba salezjanów szybko wzrosła do kilku tysięcy, byli wśród nich także Polacy. W 1860 r. jeden z pierwszych wychowanków, sierota Michał Rua został księdzem, najbliższym współpracownikiem, a następnie pierwszym następcą ks. J. Bosko. Rozwiązania organizacyjne zakładu turyńskiego stosowano w kolejnych placówkach salezjańskich we Włoszech, w innych krajach europejskich i w Ameryce (Wilk 1997, s. 761; Szmidt 2006, s. 30-31; Bosko 2002, s. 266, 268).

$\mathrm{Z}$ inicjatywy ks. J. Bosco powstała żeńska zakonna gałąź salezjańska - Zgromadzenie Córek Maryi Wspomożycielki (Congregatio Filiarum Mariae Auxiliatricis); siostry miały opiekować się dziewczętami w ten sam sposób co salezjanie chłopcami. Zgromadzenie założono w 1872 r. w Mornese w północnych Włoszech, jego celem było chrześcijańskie wychowanie młodzieży żeńskiej, szczególnie biednej i potrzebującej pomocy. Pierwszych obłóczyn dokonał biskup Giuseppe Maria Sciandra z Acqui, a ks. Bosco przyjął śluby od pierwszych 11 kandydatek i zatwierdził regulaminy nowego zakonu. Pierwszą przełożoną była Maria Mazzarello (18371881) uznana później przez Kościół za świętą za współzałożenie nowego zgromadzenia oraz wielką gorliwość i wierność ks. Bosko w formowaniu i kształtowaniu pierwszej wspólnoty oraz realizacji jej charyzmatu wychowawczego. W roku jej śmierci zgromadzenie liczyło 139 sióstr i 50 nowicjuszek, które w 27 domach rozwijały misję katechetyczną i działalność dydaktyczno-wychowawczą w Europie i na innych kontynentach (Świda 1984, s. 28-29; Mirek 2007, s. 64; Grassiano 2007, s. 6; Łoziński 2009, s. 337-338).

Istnieją także świeckie instytuty życia konsekrowanego, ich charyzmatem jest życie w ukryciu, a ich członkowie żyją w świecie i prowadzą działalność apostolską, nie ujawniając swojej przynależności do stanu konsekrowanego. Jednym $\mathrm{z}$ takich 
instytutów jest Instytut Świecki Ochotniczki Księdza Bosko (Volontarie di don Bosco). Założycielem instytutu był ks. Filip Rinaldi. W roku 1910 czternaście włoskich dziewcząt, skupionych w żeńskim oratorium sióstr salezjanek w Turynie wyraziło wolę pracy zgodnej $\mathrm{z}$ duchem św. Jana Bosko, ale realizowanym w warunkach życia świeckiego; w 1919 r. założyły pierwszą profesję, zatwierdzoną przez Stolicę Apostolską 7.08.1978 r. Ochotniczki ks. Bosko pracują na rzecz dzieci i młodzieży, ludzi ubogich, misji i powołań. Składają one śluby czystości, ubóstwa i posłuszeństwa, żyjąc w warunkach życia świeckiego. Instytut nie prowadzi własnych dzieł, ochotniczki pracują jako nauczycielki, lekarki, pielęgniarki, salowe, urzędniczki, jednocześnie podejmując inicjatywy apostolskie w pracy, w środowisku rodziny. Miejscem ich pracy jest także parafia, angażują się tam w grupy charytatywne, oratoria, rady duszpasterskie oraz inne ruchy i stowarzyszenia. W roku 2009 instytut liczył ok. 1500 członkiń w 52 krajach. W Polsce ochotniczki ks. J. Bosko działają od 1972 r., w 1991 r. Jan Paweł II beatyfikował założyciela instytutu ks. Filipa Rinaldiego (Łoziński 2009, s. 421-422; Konieczny 2010, s. 274).

\section{SALEZJANIE I SALEZJANKI NA ZIEMIACH POLSKICH}

Salezjanie na ziemie polskie zostali sprowadzeni końcem XIX w. z powodu zapotrzebowania na działalność wychowawczą wśród młodzieży. W pierwszym okresie swej działalności, a w szczególności w latach I wojny światowej aż do 1923 r. zajmowali się opieką nad dziećmi i młodzieżą osieroconą i bezdomną. Przyjmowali także zaproszenia do prowadzenia placówek oświatowo-wychowawczych wśród młodzieży i społeczeństwa. Początki nowego zgromadzenia były związane z utworzeniem placówki w Oświęcimiu, który znajdował się w ówczesnych granicach Austro-Węgier. Działalność pierwszych placówek była wzorcowa, w podobny sposób powstawały i rozwijały się kolejne dzieła zakonne na polu wychowawczym. Generał zgromadzenia ks. M. Rua udzielił zgody na otwarcie pierwszego domu zgromadzenia. Pierwszy salezjanin ks. Franciszek Trawiński przybył 15.08.1898 r. i intensywnie zajął się organizowaniem placówki (Krawiec 2006, s. 59-67). W Turynie pozostał nadal ks. Wiktor Grabelski, redaktor „Wiadomości Salezjańskich”, by szerzyć wiedzę o działalności ks. J. Bosko i salezjanów. Kolejnym przełożonym domu został ks. Emanuel Manassero, który przybył końcem 1899 r. do Oświęcimia. W roku 1899 do zakładu przyjęto pierwszych chłopców, chociaż sam budynek zakładu był jeszcze w budowie. Ofiarne składki społeczeństwa przyczyniły się do szybkiego ukończenia tego dużego gmachu. Uroczyste poświęcenie miało miejsce w 1901 r., na które przybył z Włoch generał M. Rua. Dla chłopców utworzono szkoły zawodowe i gimnazjum. W roku 1905 zakład ten stał się siedzibą 
prowincji austriacko-węgierskiej salezjanów, której pierwszym inspektorem został ks. E. Manaserro („Wiadomości Salezjańskie” 1901, R. V, nr 12, s. 253-258; Wirth 2009, s. 242-243; 25-lecie działalności salezjańskiej... 1923, s. 4-15).

W roku 1911 salezjanie objęli zarząd kolejnej placówki - był to zakład wychowawczy im. Lubomirskich w Krakowie, a dyrektorem został ks. Jan Świerc (25-lecie działalności salezjańskiej... 1923, s. 21). W 1914 r. wybuchła wojna, salezjanie otworzyli wtedy przy swoich zakładach oratoria, w których w niedziele i święta gromadziły się setki młodych osób. Chłopcy uczestniczyli we Mszy św., a następnie spędzali tam czas, zajmując się grami, pogadankami, czytaniem książek, muzyką i śpiewem, przedstawieniami teatralnymi, wycieczkami, gimnastyką, co przyczyniało się podniesienia ich ogólnego wychowania. Najubożsi otrzymywali w oratorium wsparcie żywnościowe, ubrania i bieliznę. Na spotkania w oratorium przybywało 200-300 chłopców. Fundusze na prowadzenie oratoriów czerpano z koncertów, przedstawień teatralnych, jasełek wystawianych przez chłopców dla lokalnej społeczności. Przy zakładzie działały szkoły zawodowe uczące chłopców konkretnych fachów: ślusarskiego, blacharskiego, stolarskiego, szewskiego, krawieckiego. W zakładzie maksymalnie mogło przebywać 400 podopiecznych, dla tych, którzy chcieli się kształcić, otwarto również gimnazjum klasyczne. Ważnymi czynnikami wychowawczymi było zorganizowanie dla chętnych chóru i orkiestry smyczkowej, kółka teatralnego, działało Towarzystwo Gimnastyczne i Klub Piłki Nożnej. Chłopcy biorący udział w służbie liturgicznej ołtarza zorganizowali się w Kółko Małego Kleru i „Towarzystwo św. Józefa (25-lecie działalności salezjańskiej... 1923, s. 27, 29-31). Drugi zakład salezjański powstał w Daszowie niedaleko Stryja w 1904 r., dyrektorem został ks. Piotr Tirone. W tej placówce nazwanej „Synowie Maryi” kształcono kilkudziesięciu kandydatów do stanu duchownego. W czasie wojny do domu przyjęto kilkudziesięciu chłopców, sierot wojennych, w tym sieroty ewakuowane ze Schroniska Lubomirskich w Krakowie. W roku 1920 w zakładzie przebywało 76 chłopców (25-lecie działalności salezjańskiej... 1923, s. 33-35). W roku 1907 biskup Józef S. Pelczar sprowadził salezjanów do Przemyśla. Pierwszym przełożonym był ks. dr August Hlond. Zakonnicy zajęli się pracą z młodzieżą rzemieślniczą i prowadzeniem dla nich duszpasterstwa, wychowywaniem w duchu katolickim i narodowym. W roku 1911 oddano nowy gmach, do którego przeniósł się zakład, utworzono przy nim Towarzystwo św. Stanisława dla młodzieży rzemieślniczej, a dla chętnej młodzieży szkolnej oratorium. Aby zachęcić młodzież do przebywania w oratorium, zakupiono aparat kinematograficzny do wyświetlania stosownych filmów, gramofon umożliwiający słuchanie muzyki, zorganizowano chór dla chętnych, który koncertował w kościołach i na licznych przedstawieniach dla lokalnej społeczności. Założono kapelę składającą się z 30 instrumentów, która uświetniała spotkania i występy, równocześnie powstało 
kółko gimnastyczne „Sokół”. W każdą niedzielę po Mszy św. odbywały się odczyty o różnej tematyce z dziedziny historii, polityki, sztuki, przyrody. Członkowie oratorium mogli korzystać z biblioteki. Założono kasę oszczędnościową, która uczyła wychowanków gospodarowania własnymi pieniędzmi. W Przemyślu powstała także w 1916 r. salezjańska szkoła dla organistów pod kierownictwem ks. A. Hlonda. W roku 1920 w zakładzie przebywało przeszło 100 wychowanków, w tym 40 przyszłych organistów. W ramach nauki rzemiosła chłopcy uczyli się ogrodnictwa, buchalterii i towaroznawstwa, krawiectwa (25-lecie działalności salezjańskiej... 1923, s. 36-45). W roku 1916 utworzono w Przemyślu Komitet Opieki nad opuszczoną młodzieżą, tworząc „klub uliczników”. Ze względu na dużą liczbę bezdomnych dzieci, sierot wojennych, w 1917 r. za zgodą ks. biskupa Józefa S. Pelczara otwarto dla nich Dom Opieki św. Józefa, a do prowadzenia zakładu poproszono księży salezjanów. Placówka została umieszczona w wyremontowanym gmachu koszarów. Koszty utrzymania dzieci finansowali darczyńcy, szczególnie zasłużyła się w tym dziele rodzina książąt Lubomirskich. W sytuacjach kryzysowych, kiedy brakowało podstawowych rzeczy, ratowali dom, udzielając wsparcia finansowego i materialnego (opałem, żywnością), podarowali także 10 morgów ziemi. Dom wspierały zapomogi Diecezjalnego Komitetu Opieki nad sierotami i dary stowarzyszeń amerykańskich. Liczba wychowanków w domu zwiększyła się w 1918 r. z 30 chłopców do 150 w 1923 r. (25-lecie działalności salezjańskiej... 1923, s. 46-51).

Pierwszy zakład salezjański na ziemiach polskich pod panowaniem rosyjskim powstał w Kielcach. Władze kościelne oddały parafię św. Krzyża z domem zakonowi salezjanów w lutym $1918 \mathrm{r}$. Zakonnicy utworzyli zakład wychowawczy dla sierot wojennych i opuszczonych biednych chłopców, ich liczba w 1922/23 wzrosła do 74. Uczono chłopców zawodów krawca, szewca i stolarza. Przy zakładzie powstało oratorium, do którego uczęszczało w czasie wolnym ponad 100 chłopców, którzy zorganizowali się w Towarzystwo Niepokalanego Poczęcia i św. Stanisława, Kółko Małego Kleru - służące pomocą w trakcie Mszy św., chętni i uzdolnieni grali w orkiestrze smyczkowej (25-lecie działalności salezjańskiej... 1923, s. 52-54).

Drugi zakład na ziemiach byłej Kongresówki powstał w Aleksandrowie Kujawskim, było to Gimnazjum Humanistyczne Polskiej Macierzy Szkolnej. Budowę tej placówki zainicjował ks. Franciszek Szczygłowski w 1913 r. W czasie wojny gmach dokończyli Niemcy i urządzili w nim swoje przytulisko dla żołnierzy. Po odzyskaniu niepodległości w gmachu utworzono Gimnazjum Realne Męskie, od 1919 r. szkołę poprowadzili księża salezjanie. Przy szkole zorganizowano także bursę dla 200 uczniów (25-lecie działalności salezjańskiej... 1923, s. 61-62).

W roku 1919 salezjanom ofiarowano parafię Różanystok koło Grodna, był to dawny klasztor podominikański, od 1901 r. utworzono tam klasztor sióstr prawosławnych. Końcem 1919 r. do Różanegostoku przybyli salezjanie z zamiarem 
zorganizowania szkoły powszechnej, gimnazjum, a dla starszej młodzieży duszpasterstwa. Odbudowę zniszczonych działaniami wojennymi zabudowań przerwała inwazja bolszewicka w 1920 r. W ośrodku znalazło opiekę ponad 180 sierot, głównie repatriantów z Rosji. Zorganizowano szkoły, w tym ogrodniczą, pracownie: ślusarską, stolarską, krawiecką, szewską. Docelowo placówka podjęła się opieki nad blisko 800 osobami. Do Różanegostoku do opieki nad małymi dziećmi i dziewczętami sprowadzono Córki Maryi Wspomożycielki, które zorganizowały ochronkę dla małych dzieci (25-lecie działalności salezjańskiej... 1923, s. 65-68). Kolejną instytucją salezjańską na ziemiach polskich była bursa w Białej Podlaskiej, w której od 1921 r. otoczono opieką kilkudziesięciu chłopców uczących się w gimnazjum. W Lądzie w województwie łódzkim w 1921 r. w dawnych gmachach zakonu cystersów sprowadzeni salezjanie założyli sierociniec, szkołę zawodową krawiecką i gimnazjum dla ponad 80 chłopców (25-lecie działalności salezjańskiej... 1923, s. 68-71). W roku 1914 w Antoniewie w Wielkopolsce rząd pruski wybudował duży zakład wychowawczy, w którym umieszczano przestępczą młodzież skierowaną na wychowanie przez sądy krajowe. Księża salezjanie przejęli ten ośrodek w 1922 r., było w nim 18 wychowanków. Zmienili charakter zakładu, przyjmując do niego także chłopców chętnych do nauki w szkołach zawodowych: rzemieślniczych i rolniczej. Instytucja ta straciła charakter domu poprawczego, a stała się zakładem wychowawczym prowadzonym według systemu prewencyjnego ks. J. Bosko.

W okresie dwudziestolecia międzywojennego powstało wiele nowych placówek szkolnych i wychowawczych, w 1932 r. inspektoria polska liczyła 32 placówki i ponad 500 zakonników. W 1933 r. doszło do podziału na dwie inspektorie - północną św. Stanisława Kostki z siedzibą w Warszawie i południową św. Jacka z siedzibą w Oświęcimiu. Do roku 1939 przyjęto dalszych 15 placówek, w momencie wybuchu II wojny światowej Towarzystwo Salezjańskie w Polsce liczyło 645 członków oraz posiadało 46 placówek (75 lat działalności salezjanów w Polsce... 1974, s. 12-13; Żurek 2012, s. 922-925). Rozwój wychowawczej działalności salezjanów został zahamowany wybuchem II wojny światowej. Budynki szkół i zakładów zostały zajęte przez wojska, zrabowane lub zniszczone, a personel się rozproszył. Zaraz po wojnie działalność zgromadzenia zaczęła się odradzać, w ciągu 1945 r. ruszyły wszystkie znajdujące się w nowych granicach ośrodki wychowawcze, a także nowe placówki duszpasterskie na ziemiach zachodnich i północnych. Wielka liczba dzieci i młodzieży osieroconej oraz całkowicie opuszczonej na skutek wojennego rozbicia rodzin spowodowała rozwinięcie się domów dziecka; salezjanie zorganizowali 16 sierocińców. W roku 1948 salezjanie prowadzili 8 szkół zawodowych, 4 gimnazja zawodowe, 6 gimnazjów i liceów ogólnokształcących, 4 niższe seminaria duchowne, 23 internaty, 2 bursy, kilkanaście oratoriów, 35 parafii i placówek duszpasterskich, głównie na tzw. ziemiach odzyskanych. Wszystkie te formy pracy cieszyły się 
wielkim uznaniem społeczeństwa i początkowo także władz państwowych. Od roku 1948 wraz ze zmianą warunków politycznych i społecznych działalność zakonu się skurczyła, systematycznie likwidowano placówki działalności szkolnej i wychowawczej wszystkich zakonów, do 1962 r. większość zakładów i szkół uległa zamknięciu lub przejęciu przez władze państwowe. Nastąpiło stopniowe przesuwanie się personelu do duszpasterstwa parafialnego na ziemiach zachodnich i północnych, działalność ta będąca tylko ubocznym polem pracy, stała się zasadniczym. Salezjanie rozpoczęli działalność w nowych parafiach, tworząc liczne placówki katechetyczne i duszpasterskie (75 lat działalności salezjanów w Polsce... 1974, s. 20-32). Wznowienie działalności w duchu św. J. Bosko nastąpiło dopiero po zmianach politycznych w 1989 r., kiedy pozwolono zakonom wrócić do ich wcześniejszej działalności.

Działalność salezjanek w Polsce zapoczątkowała siostra Laura Meozzi (Włoszka), która przybyła z 5 siostrami do Polski, w 1922 r. otworzyły pierwszy sierociniec w Różanymstoku w diecezji wileńskiej. W roku 1924 na prośbę biskupa wileńskiego Jerzego Matulewicza siostry przejęły od stowarzyszenia Powściągliwość i Praca zakład wychowawczy Najświętszego Serca Jezusowego w Wilnie. Następnie na prośbę władz miejskich Mysłowic na Górnym Śląsku i za zgodą tamtejszego biskupa w 1929 r. salezjanki otworzyły tam dom i zaczęły prowadzić przedszkole dla dzieci górników, oratorium świąteczne dla młodzieży, a także kursy kroju i szycia dla dziewcząt. W Różanymstoku otwarto nowicjat, a 12.10 .1929 r. odbyły się pierwsze obłóczyny piętnastu nowicjuszek. Siostra Laura Meozzi została mianowana dyrektorką domu w Wilnie, będąc jednocześnie odpowiedzialną za wszystkie domy w Polsce. W 1930 r. salezjanki na prośbę biskupa łódzkiego Wincentego Tymienieckiego otworzyły dom w Łodzi, prowadziły przedszkole, kursy zawodowe dla dziewcząt i oratorium świąteczne. W roku 1931 na prośbę salezjanów siostry otworzyły dom w Sokołowie Podlaskim i zakład wychowawczy, przy którym powstała pracownia dla dziewcząt i oratorium. W roku 1933 ks. prałat Karol Lubraniec ofiarował salezjankom teren w Sakiszkach koło Wilna, w ciągu roku zbudowano tam duży dom dla sierot nazwany Laurowem. Do zakładu tego przeniesiono chłopców z domu w Wilnie, przy sierocińcu powstała także szkoła dla okolicznych dzieci. W roku 1937 w Sokołowie Podlaskim otwarto gimnazjum dla dziewcząt, jako oddział gimnazjum salezjańskiego, w 1939 r. kardynał A. Hlond poświęcił nowy dom w Sokołowie Podlaskim, w którym od września miało się mieścić gimnazjum żeńskie Córek Maryi Wspomożycielki. W roku 1938 siostry zdążyły jeszcze otworzyć nową placówkę w Grabowie nad Prosną z przedszkolem, kursami zawodowymi i oratorium. W okresie międzywojennym powstało łącznie 9 placówek zakonu salezjanek w Polsce, siostry miały własną wizytatorię liczącą 101 sióstr, z własnym nowicjatem. Działalność poszczególnych placówek obejmowała zarówno dzieła oświatowo-wychowawcze, jak i charytatywne. Siostry prowadziły 
oratoria świąteczne, przedszkola, szkoły podstawowe, żeńskie gimnazja, szkoły zawodowe: krawiecko-bieliźniarskie, szkołę gospodarczą, kursy krawieckie i hafciarskie, kroju i szycia, pracownie robót ręcznych dla dziewcząt, stowarzyszenia Sodalicji Mariańskiej, kółka misyjne, koła rodzicielskie, Stowarzyszenia Pań Opiekunek Młodzieży (Wrońska 2012b, s. 293). Działalność zakonu utrudnił wybuch wojny, część placówek zajęło wojsko, siostry prześladowano, część z nich uciekła, kilka zesłano na Sybir i na roboty do Niemiec. W roku 1945 matka L. Meozzi opuściła Litwę z siostrami i przeszło setką wychowanków, dotarła do Pawłowic koło Leszna. Wychodząc naprzeciw naglącym potrzebom społeczeństwa, otworzyła za zgodą władz kościelnych nowe domy w Lublinie Wielkiej, Nowej Rudzie, Połczynie Zdroju oraz Wrocławiu. W roku 1946 prymas Polski kardynał A. Hlond erygował w Pogrzebiu nowicjat pod wezwaniem św. J. Bosko. W roku tym wróciły do Polski siostry zesłane na Syberię, wywiezione na roboty do Niemiec i Austrii. W roku 1947 otwarto nowe domy w Dzierżoniowie, Pieszycach, Środzie Śląskiej, Prusach, Oświęcimiu-Zasolu oraz drugi we Wrocławiu. W 1949 r. otwarto dom w Kopcu, siostry podjęły się tam pracy w nowicjacie salezjańskim i była to ostatnia fundacja matki L. Meozzi, siostrę zwolniono bowiem z obowiązku inspektorki i zastąpiła ją Matylda Sikorska. Siostra Laura umarła w opinii świętości w roku 1951 (Proński 1934, s. 45; Jakubiec 2011, s. 9-19; Grassiano 2007). Po 1948 r. ograniczono działalność zakonu, a siostry usuwano z własnych placówek, w 1963 r. zamknięto ostatnią zasadniczą szkołę zawodową w Łodzi. Dopiero po 1989 r. salezjanki przystąpiły do reaktywowania dzieł o charakterze wychowawczym. W roku 2012 siostry prowadziły 42 placówki: przedszkola, szkoły, internaty, domy dziecka, świetlice i oratoria. Zajmują się dziełem wychowania chrześcijańskiego, zgodnie z systemem prewencyjnym, podtrzymują polskie tradycje, rozwijają uczucia patriotyczne i umiłowanie ojczystej kultury. Cel ten realizują w kierowanych przez nie szkołach, przedszkolach oraz przez pracę katechetyczną w szkołach publicznych, organizowanie zajęć pozaszkolnych, prowadzenie świetlic i oratoriów (Wrońska 2012a, s. 926-928; Wrońska 2012b, s. 294-295).

\section{DZIAŁALNOŚĆ WYBRANYCH ZGROMADZEŃ}

Zgromadzeniem, które wprowadzało osiągnięcia salezjańskie w działalności opiekuńczo-wychowawczej w swoich placówkach na ziemiach polskich, byli michalici. Historia michalickich wspólnot zakonnych jest nierozerwalnie związana z postacią ks. Bronisława Markiewicza, ur. 13.07.1842 r. w Pruchniku w Galicji w wielodzietnej rodzinie. Po ukończeniu gimnazjum w Przemyślu w 1863 r. wstąpił tamże do seminarium duchownego, 15.09.1863 r. przyjął święcenia kapłańskie. 
Pracował jako wikariusz z wielkim oddaniem wśród wiejskich dzieci i młodzieży w Harcie, Szklarach, Lipniku i Bachorzu w latach 1867-1870, następnie (1870-1873) jako wikary przy katedrze w Przemyślu. Studiował na Wydziale Filozoficznym Uniwersytetu Lwowskiego (1873/74) i Uniwersytecie Krakowskim (1874/75), ale studiów nie skończył. W latach 1875-1882 pracował na probostwie w Gaci i Błażowej (zorganizował świetlice młodzieżowe), jednocześnie prowadził wykłady w seminarium przemyskim do 1885 r. Jego praca duszpasterska w Przemyślu polegała także na opiece nad ubogimi. Zakładał liczne stowarzyszenia, pomagał najbiedniejszym, organizował świetlice, czytelnie, prowadził katechizację dzieci, młodzieży i dorosłych (Głowacki 1964, s. 40-42). Ksiądz Markiewicz wyjechał do Włoch i wstąpił 15.11.1885 r. do zgromadzenia salezjanów, śluby zakonne złożył 25.03.1887 r. na ręce ks. J. Bosko. Po sześciu latach pracy we włoskich placówkach salezjańskich powrócił do Galicji i objął parafię w Miejscu k. Krosna, które na jego prośbę nazwano Miejscem Piastowym. W roku 1897 odłączył się od salezjanów, aby realizować swój ideał życia salezjańskiego w oparciu o pierwotne Ustawy św. Jana Bosko. Dzięki ofiarności społeczeństwa zbudował domy wychowawcze wraz z warsztatami do nauki zawodu. Najwięcej młodzieży skupiały ośrodki wychowawcze w Miejscu Piastowym i w Pawlikowicach k. Wieliczki. Działalność opiekuńczo-wychowawczą ks. B. Markiewicza można określić jako prekursorską w dziedzinie opieki nad dzieckiem osieroconym. Największym osiągnięciem, a jednocześnie zadaniem, które ks. Markiewicz realizował w okresie swojej działalności, było kompensowanie dzieciom osieroconym braku własnej rodziny przez odpowiednią działalność zakładu wychowawczego, który zapewniał im opiekę do momentu całkowitego usamodzielnienia. Jego koncepcja opierała się na fundamencie religii chrześcijańskiej, kładł nacisk na pracę duchową. Ważny wpływ na systematyczne pogłębianie moralności miały codzienne pięciominutowe pogadanki z wychowankami wygłaszane przez ks. B. Markiewicza, przejęte z systemu św. Jana Bosko. W swoich zakładach łączył wychowanie religijne z nauką i pracą oraz przygotowywał do życia w takich warunkach, w jakich jego wychowankowie mieli żyć w przyszłości. Dawał im pełne przygotowanie zawodowe $\mathrm{w}$ zakresie wybranych profesji. Wychowanie przez prace uczynił zasadniczą metodą wychowawczą w swoich zakładach. Wszyscy mieszkańcy zakładów mieli obowiązek pracy, przy czym zawsze była ona zgodna z ich możliwościami, zainteresowaniami i uzdolnieniami. Zalecał hartowanie wychowanków, naukę sumienności i wytrwałości. Ważne miejsce zajmowała w koncepcji ks. B. Markiewicza nauka, a także rozrywka i sport. Dzięki stosowaniu takich form pracy, jak: działalność biblioteki, teatru, organizacja licznych wycieczek, uczył ich umiejętności przeżywania i odbioru sztuki, odpowiedniego organizowania wolnego czasu. Pracowitość, prostota, skromność, powściągliwość, poprzestawanie na małym to cechy osobowościowe propagowane i kształtowane w koncepcji 
ks. B. Markiewicza. Wychowanie zakładowe odznaczało się życzliwą atmosferą, miłością, troskliwością i życzliwością, opieką ze strony personelu i starszych kolegów. Idea wychowania patriotycznego u ks. B. Markiewicza była wpisana w ogólne pojęcie wychowania narodowego i stanowiła jeden $\mathrm{z}$ filarów jego koncepcji wychowawczej (Szewc 2012, s. 301-303; Kustra 2012, s. 501-503, 526). W roku 1898 utworzył Towarzystwo Powściągliwość i Praca, rozpoczął wydawanie miesięcznika pod tym samym tytułem (Różański 2005, s. 32-37; Łoziński 2009, s. 87-88; Różański 2008, s. 795-796). Zrzeszenie to z czasem przekształciło się w Zgromadzenie św. Michała Archanioła, a jego żeńska gałąź w Zgromadzenie Sióstr św. Michała Archanioła (Congregatio Sororum Sancti Michaelis Archangeli). Ks. B. Markiewicz dostrzegał potrzebę opieki nad opuszczonymi małymi dziećmi, dziewczętami, chorymi i dlatego powołał do istnienia żeńską gałąź zgromadzenia. Zgromadzenie michalitek zostało założone w Miejscu Piastowym w 1897 r. przez ks. B. Markiewicza przy współpracy s. Anny Kaworek. Głównym ich celem była działalność edukacyjno-wychowawcza wśród dzieci i młodzieży (głównie sierot) oraz opieka nad opuszczonymi i chorymi. Od 1898 r. s. A. Kaworek stanęła na czele tworzącego się zgromadzenia, które zostało zatwierdzone w $1928 \mathrm{r}$. Zgromadzenie prowadziło domy w Działkowicach, Miejscu Piastowym, Truskawcu i Wysokiej (Proński 1934, s. 43).

Z osiągnięć systemu wychowawczego ks. J. Bosko wzorce czerpały także inne zgromadzenia zakonne, m.in. Zgromadzenie Sióstr Pasterek od Opatrzności Bożej (Congregatio Sororum Divini Pastoris a Providentia Divina), które zostało założone przez s. Marię Karłowską (1865-1935) w Poznaniu. Założycielka wychowała się w zubożałej rodzinie ziemiańskiej, była świadoma, że przyczyną upadku moralności wielu jej rówieśnic była bieda. Postanowiła temu zapobiec, organizując działalność opiekuńczą, charytatywną i pedagogiczną, wnosząc znaczny wkład w rozwój pedagogiki pasterskiej na rzecz resocjalizacji prostytutek. Początki zgromadzenia sięgają 1892 r., kiedy to s. M. Karłowska udzielała pomocy chorym i ubogim, dziewczętom i kobietom z marginesu społecznego, chorym prostytutkom. Po okresie pracy w ukryciu, w 1894 r. powołała do istnienia zakład Dobrego Pasterza, w którym umieściła swoje wychowanki, a po nim powołała do życia nowe zgromadzenie. Pomimo trudności dzieło to przetrwało dzięki wsparciu hrabiny Anieli Potulickiej, która zakupiła dla zakładu posiadłość we wsi Winiary k. Poznania. W celu zapewnienia ciągłości i trwałości tego rodzaju apostolatu s. M. Karłowska założyła nowe zgromadzenie, którego charyzmatem była praca dla dziewcząt i kobiet moralnie słabych, przygotowanie ich do odpowiedniego życia $\mathrm{w}$ społeczeństwie, umocnienie ich wiary i moralności oraz wykształcenie i przygotowanie zawodowe (Łoziński 2009, s. 318-319). Siostra Karłowska pracowała $\mathrm{z}$ dziewczętami w Winiarach, ośrodku stworzonym na obrzeżach Poznania. 
Diecezjalne zatwierdzenie Zgromadzenia Sióstr Pasterek od Opatrzności Bożej nastąpiło 13.04.1909 r., a 24.05.1967 r. zostało potwierdzone przez Stolicę Apostolską. Zgromadzenie w 1909 r. uzyskało zatwierdzenie diecezjalne, a w 1928 r. potwierdzono konstytucje. Siostra s. M. Karłowska zmarła w Pniewitem w opinii świętości, została beatyfikowana 6.06.1997 r. przez papieża Jana Pawła II (Łoziński 2009, s. 319). Jeszcze za swego życia s. M. Karłowska otworzyła dziewięć placówek, których działalność cieszyła się uznaniem ze strony zarówno władz kościelnych, jak i państwowych w: Poznaniu, Lublinie, Toruniu, Bydgoszczy, Topolnie, Łodzi Radogoszczy, Pniewitem, Dębowej Łące oraz Jabłonowie Pomorskim. Objęła w nich resocjalizacją 5 tysięcy kobiet i dziewcząt: wenerycznie chorych, prostytutek oraz więźniarek (Myszka 2012, s. 406-407). Nie otrzymywała przy tym żadnych dotacji państwowych na prowadzenie swej działalności. W tej sytuacji w domach zgromadzenia starano się o różnego rodzaju dodatkowe źródła utrzymania, organizując warsztaty rzemieślnicze (tkackie, krawieckie, trykotarskie, koszykarskie, szewskie), organizowano małe zakłady produkcyjne, dochodowe uprawy rolne i hodowle. Matka wykazywała się pod tym względem dużym zmysłem organizatorskim i pomysłowością. Zaniedbane majątki z przynależnymi do nich gruntami rolnymi dzięki sumiennej i dobrze zaplanowanej pracy podnosiła na wysoki poziom, co dawało zyski i podstawę do utrzymania licznych placówek. Ważną rolę Zgromadzenie Sióstr Pasterek odegrało w resocjalizacji kobiet i dziewcząt polskich. Placówki zróżnicowały się w zależności od tego, w jakim wieku były wychowanki i z jakich powodów się w nich znalazły. Zakłady wychowawcze ze względu na podopieczne można podzielić na: 1) wychowanki małoletnie: Lublin (Wiktoryn) i Romanów; 2) przestępczynie, wychowanki przyprowadzane pod przymusem: Poznań; 3) byłe pacjentki szpitali wenerycznych, wychowanki zasługujące na zaufanie: Topolno i Romanów; 4) wychowanki pragnące pozostać pod opieką zgromadzenia: Pniewie; 5) szpitale dla kobiet wenerycznie chorych: Toruń, Łódź. Praca ze zdemoralizowanymi kobietami była bardzo trudna, często wręcz niebezpieczna ze względu na ich agresywne zachowanie, część z nich była przyprowadzana do zakładu przez policję lub rodzinę. Praca wychowawcza w domach Dobrego Pasterza polegała na zapobieganiu złemu postępowaniu, co wymagało czujności. Siostra pasterka powinna przewidywać błędy i zapobiegać im, eliminować okazję do złego zachowania. Założycielka sióstr pasterek sformułowała instrukcje dotyczące oddziaływania uprzedzającego, co przypomina salezjańską prewencyjną metodę wychowawczą. Wychowanki były lekkomyślne, leniwe, często kłamały, wpadały w depresję. Siostry czuwały nad nimi, nie spuszczały ich z oczu, starały się nie zniechęcać błądzących ostrymi upomnieniami, wspierały zachętą, czuwały $\mathrm{z}$ taktem, nie dając im odczuć, że są dozorowane. System wychowawczy opierał się na religii i na osobistym przykładzie Chrystusa, który nie pozwolił 
rzucić kamieniem w jawnogrzesznicę i przebaczył Magdalenie. Pracę naznaczoną pokutą, jako pierwszą i podstawową metodę wychowania resocjalizacyjnego, przyjęto za podstawę zewnętrznej i wewnętrznej przemiany podopiecznych. Metodę tę przełożona uznała za pierwszą, ponieważ dostrzegła, że główną przyczyną demoralizacji dziewcząt i kobiet był brak pracy, lenistwo lub niezawiniona nieznajomość religijnej motywacji obowiązku pracy nałożonej na każdego człowieka. Z czasem następowało odrodzenie duchowe dziewcząt, zmiana obyczajów i powrót do wartości chrześcijańskich; resocjalizacja ta odbywała się też przez pracę, zdobywanie zawodu i nowych umiejętności życiowych. Przeciętnie $80 \%$ dziewcząt po spędzeniu kilku lat w zakładzie wracało do normalnego życia. Najczęściej zakładały rodziny i pozostawały przykładnymi żonami i matkami, niektóre zostawały do śmierci w domach Dobrego Pasterza. Już w 1898 r. wśród wychowanek winiarskich znajdowały się tzw. aspirantki, które chciały poświęcić się Bogu na całe życie. Wraz z rozwojem zgromadzenia i jego posługi apostolskiej część nawróconych wychowanek, które mogły już opuścić dom, chciała pozostać dłużej lub nawet na stałe pod opieką zgromadzenia i służyć mu swoją pracą oraz pomocą. Zgłaszały się też osoby spoza zakładu, pragnące pokutować za siebie i za cały świat. Z czasem matka Karłowska utworzyła dla nich specjalną grupę i dała im nazwę - Stowarzyszenie Sióstr św. Marii Magdaleny. Magdalenki otrzymały aprobatę kościelną w 1924 r., zajmowały się wszystkimi pracami gospodarczymi w domach zgromadzenia (Wybór pism Marii Karłowskiej... 1981, s. 27-32, 38-42; Karłowska 2012, s. 67-70; Myszka 2012, s. 313-416, 420, 424). M. Karłowska próbowała także zająć się wychowaniem chłopców, którzy dopuścili się różnych przestępstw (złodziejstwo, bandytyzm), w 1902 r. do zakładu w Winiarach przyjęła pierwszych podopiecznych. Chłopcy w wieku 12-16 lat pracowali w polu, uprawiali stolarkę, wiązali sieci, wyplatali koszyki. Opiekował się nimi brat Kazimierz Wasilewski z zakonu bonifratrów. Matce Karłowskiej przyświecał w prowadzeniu zakładu przykład ks. Jana Bosko. Traktowała ona chłopców z wielką dobrocią i łagodnością. Czasami wychodziła z nimi na przechadzki, uczyła katechizmu, dbała o ich wyżywienie i odzież. Usiłowała uzyskać zgodę na sprowadzenie salezjanów wychowawców do prowadzenia zakładu dla chłopców, jednak władze pruskie nie wydały zgody na sprowadzenie tego zakonu do archidiecezji poznańskiej. Zakład uległ z czasem zamknięciu, z 16 chłopców, którzy tam przybyli jako pierwsi, 4 pozostało na stałe, aby pracować na roli (Karłowska 2012, s. 48-51). Zgromadzenie Sióstr Pasterek weszło w okres dynamicznego rozwoju po odzyskaniu przez Polskę niepodległości. Swoją działalnością resocjalizacyjną przyczyniało się do odrodzenia społeczeństwa polskiego. Obecnie zgromadzenie prowadzi 20 domów w Polsce, zajmując się dziewczętami zagrożonymi demoralizacją, alkoholizmem, uzależnieniami, oraz 3 ośrodki opiekuńczo-wychowawcze zamknięte w Poznaniu, Topolnie 
i Pniewitem. Oprócz mieszkania, wyżywienia, leczenia dziewczęta mają szansę na rozwój umysłowy, moralny, religijny, patriotyczny i estetyczny, zmianę życia, ukończenia szkoły i zdobycia zawodu. We wszystkich ośrodkach obowiązują podobne zasady: miłość wychowawcza, szacunek dla godności osoby ludzkiej, odwołanie do godności osobistej wychowanki oraz metody, którymi są praca, nauczanie i modlitwa (Myszka 2012, s. 426-431).

\section{PODSUMOWANIE}

Po zakończeniu II wojny światowej Polska dostała się w radziecką strefę wpływów. Nowe komunistyczne władze od początku zaczęły zwalczać Kościół, wprowadzając nową świecką ideologię, a w szczególności wszystkie zgromadzenia zakonne, które prowadziły placówki kształcące i opiekuńcze dla dzieci i młodzieży. Usunięto zakony z prawie wszystkich szkół i placówek wychowawczych. W zaistniałej sytuacji salezjanie przejęli parafie na Ziemiach Odzyskanych, ich działalność została przesunięta $\mathrm{z}$ wychowawczej na akcję duszpasterską. Podobnie pozostałe zakony zmuszono do zmiany charakteru swej działalności. Salezjanki włączyły się w duszpasterstwo parafialne, prowadząc katechizację dzieci i młodzieży, a później różne grupy formacyjne, zwłaszcza Ruch Światło-Życie. Siostry pasterki zaczęły prowadzić domy samotnej matki, zakłady dla nieuleczalnie chorych kobiet. Dopiero zmiany polityczne w 1989 r. pozwoliły zakonom wrócić do ich charyzmatów: realizując w Kościele dzieło wychowania chrześcijańskiego zgodnie z systemem prewencyjnym św. Jana Bosko. W roku 2015 minęła dwusetna rocznica urodzin księdza Bosko, jego dzieło trwa, a posłannictwo salezjańskie rozwija się w czasach współczesnych bardzo dynamicznie (Villanueva 2009, s. 4-9). Według ks. Bosko najlepszym sposobem bycia użytecznym w społeczeństwie jest dobrze wychowywać młodzież, formując „dobrych chrześcijan i uczciwych obywateli”, dążąc także do wychowania młodego pokolenia $\mathrm{w}$ wartościach narodowych i patriotycznych. Cała działalność wychowawcza i opiekuńcza jest zorganizowana w tym duchu i w duchu dbałości o rozwój kultury polskiej. Prowadzona jest działalność duszpasterska i wychowawcza wśród młodzieży i społeczeństwa w ogóle. Ruch salezjański obejmuje samą młodzież, rodziców, współpracowników, wolontariuszy, sympatyków salezjańskiego dzieła, dobroczyńców, także niechrześcijan, w szczególności w krajach azjatyckich. 


\section{LITERATURA}

25-lecie działalności salezjańskiej w Polsce, 1923, Mikołów.

75-lat działalności salezjanów w Polsce. Księga Pamiątkowa, 1974, R. Popowski, S. Wilk, M. Lewko (red.). Łódź-Kraków, Towarzystwo Salezjańskie.

Bosco H., Matt Von L., 2000, Ksiądz Bosko. Warszawa, Wydawnictwo Salezjańskie. Bosco T., 1990, Ksiądz Bosko wychowawca. Warszawa, Wydawnictwo Salezjańskie. Bosco T., 2002, Złote myśli Księdza Bosko. Warszawa, Wydawnictwo Salezjańskie. Bosko J., 2002, Wspomnienia Oratorium. Warszawa, Wydawnictwo Salezjańskie.

Cian L., 2001, Wychowanie w duchu ks. Bosko. Warszawa, Wydawnictwo Salezjańskie.

Głowacki M., 1964, Markiewicz - wychowawca. „Zeszyty Naukowe KUL”, t. 7, 3(27), 39-52.

Gorys E., 2007, Leksykon świętych. Warszawa, Klub dla Ciebie.

Grassiano M.D., 2007, W kraju brzóz. Warszawa, Wydawnictwo Salezjańskie.

Jakubiec J., 2011, Poemat dobroci. Warszawa, Wydawnictwo Salezjańskie.

Karłowska M., 2012, Pisma. Św. Marii Magdaleny miłość i pokuta, t. 4: Notatki z rekolekcji, W. Rozenkowski, G. Dobrska (oprac.). Pelplin, Wydawnictwo „Bernardinum".

Konieczny M., 2008, Michalitki, Congregatio Sororum Sancti Michaeli Archanieli (CSSMA). W: Encyklopedia katolicka, t. 12. Lublin, Towarzystwo Naukowe KUL, 797-798.

Konieczny M., 2010, Ochotniczki Księdza Bosco, Volontaire di Don Bosco (VDB). W: Encyklopedia katolicka, t. 14. Lublin, Towarzystwo Naukowe KUL, 274.

Krawiec J., 2006, Działalność religijno-patriotyczna salezjanów w Oświęcimiu. Kraków, Wydawnictwo Poligrafia Inspektoratu Towarzystwa Salezjańskiego.

Kustra Cz., 2012, Pedagogia michalitów [Zgromadzenie Świętego Michała Archanioła]. W: Pedagogie katolickich zgromadzeń zakonnych. Historia i współczesność, t. 1. Kraków, Wydawnictwo Impuls, 499-536.

Łobocki M., 2004, Teoria wychowania w zarysie. Kraków Wydawnictwo Impuls, 87.

Łoziński B., 2009, Leksykon zakonów w Polsce. Warszawa, Katolicka Agencja Informacyjna.

Łuczyński A., 2012, System prewencyjny w działalności wychowawczej św. Jana Bosko. W: S. Wilk, A. Kicinski i in. (red.), Drogowskazy wychowania. Lublin, Wydawnictwo KUL, 241-262.

Mirek A., 2007, Atlas żeńskiego ruchu zakonnego na ziemiach polskich $w$ XIX i XX wieku. Lublin, Wydawnictwo Petit.

Misiaszek K., 2010, Salezjańska metoda wychowawcza. W: Encyklopedia pedagogiczna XXI wieku (suplement). Warszawa, Wydawnictwo Żak, 455-458. 
Misiaszek K., 2012, Pedagogia salezjanów [Towarzystwa św. Franciszka Salezego]. W: J. Kostkiewicz (red.), Pedagogie katolickich zgromadzeń zakonnych. Historia i wspólczesność, t. 1. Kraków, Wydawnictwo Impuls, 229-269.

Myszka A., 2012, Pedagogia sióstr pasterek [Zgromadzenia Sióstr Pasterek od Opatrzności Bożej]. W: J. Kostkiewicz (red.), Pedagogie katolickich zgromadzeń zakonnych. Historia i współczesność, t. 1. Kraków, Wydawnictwo Impuls, 405-443.

Pietrzykowski J., 2012, Salezjanie, Towarzystwo św. Franciszka Salezego. 1. Geneza i dzieje. W: Encyklopedia katolicka, t. 17. Lublin, Wydawnictwo Naukowe KUL, 920-922.

Proński M., 1934, Zakony żeńskie w Polsce. Kraków, Wydawnictwo „Powściągliwość i Praca”.

Różański M., 2005, 2009, CSMA, Historia wspólnot michalickich. Towarzystwo Powściagliwość i Praca (1898-1921). Michalici do 1951 roku. Michalitki do roku 1956, t. 1, 2. Marki, Wydawnictwo Michalineum.

Różański M., 2008, Michalici, Zgromadzenie św. Michała Archanioła, Congregatio Sancti Michaeli Archanieli (CSMA). W: Encyklopedia katolicka, t. 12. Lublin, Wydawnictwo Naukowe KUL, 795-796.

Styrna S., 1974, Zgromadzenie Salezjańskie w Polsce w poszukiwaniu form odpowiedzi na potrzeby wychowawcze i duszpasterskie w latach 1898-1974. W: R. Popowski, S. Wilk, M. Lewko (red.), 75 lat działalności Salezjanów w Polsce. Księga Pamiątkowa. Łódź-Kraków, Towarzystwo Salezjańskie.

Szewc I., 2012, Koncepcja wychowawcza bł. Bronisława Markiewicza jako drogowskaz wychowania na dzisiejsze czasy. W: S. Wilk i in. (red.), Drogowskazy wychowania. Lublin, Wydawnictwo Naukowe KUL, 291-306.

Szmidt S., 2006, Święci, błogosławieni, słudzy Boży Rodziny Salezjańskiej. Warszawa, Wydawnictwo Salezjańskie.

Świda A., 1984, Towarzystwo Salezjańskie (Rys historyczny). Kraków, Inspektorat Towarzystwa Salezjańskiego.

Villanueva P.Ch., 2009, Rodzina Salezjańska wczoraj i dziś: nasienie stało się drzewem a drzewo lasem. Kraków, Wydawnictwo Poligrafia Salezjańska.

„Wiadomości Salezjańskie” 1897, R. I, nr 1, s. 9-13; 1899, t. 3, nr 10, 11, s. 291-297; 1901, R. V, nr 12, 253-258.

Wilk S., 1997, Jan Bosco św. W: Encyklopedia katolicka, t. 7. Lublin, Wydawnictwo Naukowe KUL, 760-762.

Wirth M., 2009, Ksiądz Bosko i Rodzina Salezjańska, dzieje i nowe wyzwania (18152000). Kraków, Wydawnictwo Salezjańskie.

Wrońska H., 2012a, Salezjanki, córki Maryi Wspomożycielki, Figlie di Maria Ausiliatrice, zgromadzenie zakonne. W: Encyklopedia katolicka, t. 17. Lublin, Wydawnictwo Naukowe KUL, 926-928. 
Wrońska H., 2012b, Pedagogia salezjanek [Zgromadzenia Córek Maryi Wspomożycielki]. W: J. Kostkiewicz (red.), Pedagogie katolickich zgromadzeń zakonnych. Historia i wspótczesność, t. 1. Kraków, Wydawnictwo Impuls, 271-307.

Wybór pism Marii Karłowskiej, 1981, J.R. Bar (oprac.). Warszawa, Zakład Graficzny Politechniki Warszawskiej.

Żurek W.W., 2012, Salezjanie, Towarzystwo św. Franciszka Walezego, Societas s. Francisco Silesii, zgromadzenie zak. 2. w Polsce. W: Encyklopedia katolicka, t. 17. Lublin, Wydawnictwo Naukowe KUL, 922-925. http://www.michalici.pl/ [dostęp: 6.03.2016].

\title{
THE EFFECT OF SAINT JOHN BOSCO'S EDUCATIONAL SYSTEM ON
}

\author{
THE CARING END EDUCATIONAL ACTIVITY OF CONGREGATIONS IN POLAND
}

\begin{abstract}
The priest Saint Jan Bosco (1815-1888) was an eminent educator of the youth and the creator of an original educational system called a preventive one. John Bosco established a new congregation of Salesian brothers who took care of and educated the former juvenile prisoners as well as abandoned and orphaned boys from the neighbourhood of Turin. He entrusted a new congregation of Daughters of Mary Help of Christians (Salesian Sisters) with the task of taking care of poor and orphaned girls. The system was based on the principles of Christian education, on the Eucharistic life of the youth who were given wise love, friendship and goodness in the institutions and oratories. The youth attended vocational schools and workshops organized specially for them and those gave them a chance for a better life. Other religious orders concerned with educating children and youth in the Polish territories also draw from the Salesian educational models. These include Male and Female Congregations of Saint Michael the Archangel, Congregation of Sisters Shepherdesses of Divine Providence as well as lay associations within the so-called Salesian Family.
\end{abstract}

Keywords: Salesians, preventive system, religious orders, care, Christian education, orphanhood and abandonment 